Available online at: http://ejournal.unpas.ac.id/index.php/litigasi

Litigasi, Vol. 17(2), 2016, 3427 - 3466

DOI: http://dx.doi.org/10.23969/litigasi.v17i2.143

\title{
URGENSI KEBERADAAN GBHN DALAM SISTEM KETATANEGARAAN REPUBLIK INDONESIA
}

\section{Janpatar Simamora}

Fakultas Hukum Universitas HKBP Nommensen Medan, Jln. Sutomo No. 4A Medan - Sumatera Utara 20234, HP: 08139297 0123, Email: patarmora_81@yahoo.co.id.

\begin{abstract}
ABSTRAK
Salah satu poin mendasar dari amandemen UUD NRI Tahun 1945 adalah dihapuskannya Garis-Garis Besar Haluan Negara (GBHN) dalam sistem ketatanegaraan Republik Indonesia. Sebagai konsekuensinya, maka tujuan dan sasaran pembangunan nasional seakan kurang fokus, tidak terarah dan sulit diukur tingkat keberhasilannya. Sementara keberadaan Rencana Pembangunan Jangka Panjang Nasional (RPJPN) yang dimaksudkan untuk menggantikan posisi GBHN, sampai saat ini belum belum mampu dijadikan sebagai panduan pembangunan nasional. Untuk itu, maka upaya menghidupkan kembali GBHN menjadi sangat urgen dalam rangka mewujudkan masyarakat Indonesia yang adil dan makmur sebagaimana dicita-citakan dalam Pembukaan UUD NRI Tahun 1945. Mengembalikan keberadaan GBHN juga akan berdampak positif pada upaya menjaga dan mengawal eksistensi MPR sebagai salah satu lembaga negara.
\end{abstract}

Kata Kunci: GBHN, UUD 1945, kewenangan, pembangunan nasional, MPR.

\begin{abstract}
One of the fundamental points of the amended of Indonesian Constitution of 1945 is the removal of the Outlines of State Policy (Guidelines) in the constitutional system of the Republic of Indonesia. As a consequence, the goals and objectives of national development seemed to lack of focus, unfocused and difficult to measure the success rate. While the existence of the National Long-Term Development Plan (RPJPN) intended to replace the Guidelines, until now there has not been able to serve as a guide to national development. To that end, efforts to revive the guidelines are extremely vital in order to realize a fair society and a prosperous Indonesia as aspired to in the preamble of the Constitution of 1945. Returning NRI existence of the guidelines will also have a positive impact on maintaining and guarding the existence of the Assembly as one of the state institutions.
\end{abstract}

Keywords: Guidelines, 1945, the authority, the national development, MPR.

Copyright (C) 2016, LITIGASI, p-ISSN: 0853-7100; e-ISSN: 2442-2274 
Available online at: http://ejournal.unpas.ac.id/index.php/litigasi

Litigasi, Vol. 17(2), 2016, 3427 - 3466

DOI: http://dx.doi.org/10.23969/litigasi.v17i2.143

\section{PENDAHULUAN}

Sejak digulirkannya arus reformasi di Indonesia pada tahun 1997 -

1998, beragam perubahan mendasar, khususnya dalam bidang kehidupan ketatanegaraan Republik Indonesia terus mengalami dinamika perkembangan yang begitu pesat. Penataan sistem ketatanegaraan Republik Indonesia sampai dengan seluruh sendi-sendi kehidupan berbangsa dan bernegara terus mengalami pembenahan. Dilakukannya perubahan sebanyak 4 kali terhadap Undang-Undang Dasar Negara Republik Indonesia tahun 1945 adalah merupakan salah satu wujud nyata betapa agenda reformasi dalam bidang kelembagaan negara sudah mengalami perkembangan yang cukup signifikan.

Dalam bidang kekuasaan legislatif sebagai salah satu cabang kekuasaan menurut ajaran Trias Politika yang dipelopori oleh Montesquieu dan kemudian diadopsi dalam sistem ketatanegaraan Republik Indonesia, lahirnya Dewan Perwakilan Daerah (DPD) adalah merupakan salah satu wujud nyata penataan kelembagaan negara. Kendati kemudian dalam perjalanannya bahwa kedudukan DPD belum mampu membawa peran yang begitu mendasar dalam cabang kekuasaan legislatif, namun hal itu patut dimaknai sebagai sebuah dinamika perubahan yang tidak mungkin dapat berjalan sempurna dalam waktu yang relatif singkat.

Demikian juga dalam bidang kekuasaan yudikatif bahwa lahirnya Mahkamah Konstitusi (MK) sebagai salah satu lembaga pelaksana kekuasaan kehakiman di samping Mahkamah Agung (MA) adalah merupakan wujud nyata adanya reformasi kelembagaan dalam bidang kekuasaan yudisial. Penataan kelembagaan dalam bidang

Copyright @ 2016 , LITIGASI, p-ISSN: 0853-7100; e-ISSN: 2442-2274 
Available online at: http://ejournal.unpas.ac.id/index.php/litigasi

Litigasi, Vol. 17(2), 2016, 3427 - 3466

DOI: http://dx.doi.org/10.23969/litigasi.v17i2.143

kekuasaan kehakiman kian menunjukkan tahap penyempurnaan seiring dengan lahirnya Komisi Yudisial dalam rangka mengawal reformasi serta pengawasan perilaku para pendekar keadilan yang bernaung di bawah kekuasaan kehakiman. Dalam bidang kekuasaan eksekutif, arus reformasi juga telah menggiring Bangsa Indonesia menuju penataan system pemerintahan yang lebih efektif dan mampu menunjukkan jati dirinya sebagai Negara dengan sistem pemerintahan presidensial. Kendatipun kemudian bahwa sistem pemerintahan presidensial murni belum bisa direalisasikan di Indonesia, namun setidaknya upaya untuk menuju pembangunan sistem pemerintahan yang lebih mengarah pada penegasan salah satu sistem pemerintahan yang memiliki ciri khas tersendiri telah dimulai oleh bangsa ini.

Selain itu, beberapa tuntutan reformasi yang tidak kalah urgennya untuk segera diwujudnyatakan juga telah menunjukkan kemajuan yang cukup berarti. Lihat saja misalnya upaya pemberantasan korupsi yang begitu gencar digelorakan pemerintah dan seluruh elemen masyarakat negeri ini. Banyaknya para pejabat negara maupun kalangan swasta yang kemudian berhasil diseret ke meja hijau pengadilan guna mempertanggungjawabkan perbuatannya adalah bukti nyata bahwa gerakan pemberantasan korupsi di tanah air terus saja mengalami peningkatan dukungan yang begitu kuat.

Hal yang sama juga terjadi dalam bidang penegakan hukum, pencabutan dwi fungsi $A B R I$, tidak ketinggalan pula bahwa agenda untuk melakukan amandemen UUD NRI Tahun 1945 dalam rangka penyempurnaannya juga terus mengalami dinamika yang cukup membanggakan. Demikian juga dengan proses pematangan

Copyright @ 2016 , LITIGASI, p-ISSN: 0853-7100; e-ISSN: 2442-2274 
Available online at: http://ejournal.unpas.ac.id/index.php/litigasi

Litigasi, Vol. 17(2), 2016, 3427 - 3466

DOI: http://dx.doi.org/10.23969/litigasi.v17i2.143

demokrasi serta upaya mengembalikan kedaulatan ke tangan rakyat secara langsung juga telah dibangun sedemikian rupa. Proses pemilihan Presiden dan Wakil Presiden serta pemilihan kepala daerah, baik untuk tingkat Provinsi, Kabupaten maupun Kota yang sebelumnya dilakukan dengan system pemilihan melalui lembaga perwakilan, kini telah dikembalikan ke tangan rakyat.

Sejalan dengan diadopsinya sistem pemilihan kepala daerah secara langsung oleh rakyat, maka sejalan dengan itu pula, konsep otonomi daerah dengan prinsip kewenangan seluas-luasnya juga telah turut direalisasikan. Hal ini dilakukan dalam rangka mengimbangi kekuasaan yang dimiliki oleh para kepala daerah agar kemudian tidak terbentur dalam jeratan kekuasaan pusat yang begitu kuat sebelum terjadinya reformasi. Dengan demikian, maka para kepala daerah diberikan keleluasaan dalam bertindak guna mengelola daerahnya masing-masing sesuai dengan tuntutan maupun aspirasi masyarakat setempat. Tentu harus diakui bahwa seluruh agenda reformasi, baik yang telah berhasil diwujudnyatakan maupun yang sedang berada dalam proses pembenahan memiliki resiko tersendiri yang sudah barang tentu harus dipikul bangsa ini. Mahalnya pelaksanaan pemilihan kepala daerah secara langsung, masih ditemukannya berbagai keganjilan dalam rangka penegakan hukum, belum sempurnanya agenda reformasi birokrasi dimana masih sarat dengan berbagai praktik yang mengarah pada perbuatan Korupsi, Kolusi dan Nepotisme (KKN) serta belum dimaknainya otonomi daerah menurut hakikat awalnya haruslah dipahami sebagai sebuah konsekuensi dari suatu perubahan, apalagi ketika perubahan itu masih dalam tahap penyesuaian dan sedang dalam proses pembenahan.

Copyright @ 2016, LITIGASI, p-ISSN: 0853-7100; e-ISSN: 2442-2274 
Available online at: http://ejournal.unpas.ac.id/index.php/litigasi

Litigasi, Vol. 17(2), 2016, 3427 - 3466

DOI: http://dx.doi.org/10.23969/litigasi.v17i2.143

Dari sekian banyak perubahan dimaksud, satu hal yang patut dicatat bahwa Bangsa Indonesia saat ini setidaknya telah memulai dan bahkan telah merasakan berbagai perubahan mendasar dalam praktik kehidupan sehari-hari. Pintu untuk menuju gerbang Negara dan pemerintahan yang berkeadilan dan berkemakmuran sebagaimana yang digariskan oleh para the founding father bangsa dalam pembukaan UUD NRI Tahun 1945 kian terbuka lebar seiring dengan dilakukannya pembenahan menyeluruh terhadap roda pergerakan dan perjalanan Bangsa Indonesia.

Namun demikian, harus diakui bahwa terdapat beberapa hal yang patut dikaji ulang pasca reformasi. Satu dari sekian banyak persoalan yang patut dikaji ulang pasca reformasi adalah langkah menghapuskan Garis-Garis Besar Haluan Negara (GBHN) yang sebelumnya dilakukan seiring dengan dilakukannya amandemen terhadap UUD NRI Tahun 1945. Sejak dihapuskannya kewenangan Majelis Permusyawaratan Rakyat (MPR) dalam menetapkan GBHN, maka sejak saat itu pula, Bangsa Indonesia seolah kehilangan acuan dalam menjalankan roda pemerintahan, khususnya roda pembangunan. Hilangnya GBHN telah mengakibatkan hilangnya sarana pemandu pelaksanaan pembangunan nasional yang telah terbukti mampu memandu pemerintahan orde baru dalam melaksanakan kegiatan pembangunan berturut-turut sejak tahun 1973-1998 (Cholid Mahmud, 2012:1).

GBHN adalah merupakan haluan negara tentang penyelenggaraan negara dalam garis-garis besar sebagai pernyataan kehendak rakyat secara menyeluruh dan

Copyright @ 2016 , LITIGASI, p-ISSN: 0853-7100; e-ISSN: 2442-2274 
Available online at: http://ejournal.unpas.ac.id/index.php/litigasi

Litigasi, Vol. 17(2), 2016, 3427 - 3466

DOI: http://dx.doi.org/10.23969/litigasi.v17i2.143

terpadu. Sebagai haluan negara, maka tentu dapat dipahami bahwa keberadaan GBHN itu sendiri dalam pelaksanaan roda pemerintahan sangatlah dibutuhkan. Melalui GBHN, maka arah dan tujuan perjalanan roda pemerintahan akan dapat lebih mudah dipahami sehingga cukup memudahkan dalam mengoreksi tingkat keberhasilan dan pencapaian yang ditorehkan oleh suatu pemerintahan yang sedang berkuasa.

Kendati kemudian ditemukan sejumlah program lain seperti Rencana Pembangunan Jangka Panjang Nasional (RPJPN) yang dibentuk dan ditawarkan guna menggantikan posisi GBHN, namun harus diakui bahwa hal itu belum mampu dibangun sebagai konsepsi yang lebih operasional agar tujuan dan proses pembangunan tidak terombang-ambing oleh tarik menarik kepentingan dari berbagai pihak. Disinilah keberadaan RPJPN belum mampu mengimbangi atau menggantikan keberadaan GBHN sebagai penunjuk arah maupun kompas bagi perjalanan Bangsa Indonesia ke depan. Bahkan salah satu alasan sejumlah pihak yang pro terhadap upaya menghidupkan kembali GBHN didasarkan fakta yang diperoleh di lapangan yang menunjukkan bahwa baik Rencana Pembangunan Jangka Menengah (RPJM) maupun RPJP tidak mampu memberikan solusi untuk menyatukan visi pembangunan di seluruh tingkatan dalam rangka menciptakan kesejahteraan masyarakat (Robinson Sembiring, 2011).

Ketika GBHN dihapuskan dari system ketatanegaraan bangsa ini, maka akan teramat sulit untuk mengukur tingkat keberhasilan suatu pemerintahan yang dijalankan. Sebab tidak ditemukan hal apa saja yang menjadi ukuran maupun kriteria

Copyright @ 2016 , LITIGASI, p-ISSN: 0853-7100; e-ISSN: 2442-2274 
Available online at: http://ejournal.unpas.ac.id/index.php/litigasi

Litigasi, Vol. 17(2), 2016, 3427 - 3466

DOI: http://dx.doi.org/10.23969/litigasi.v17i2.143

keberhasilan terhadap suatu pemerintahan secara nyata. Jujur harus diakui bahwa langkah penghapusan GBHN bukanlah salah satu tujuan dari reformasi. Hapusnya keberadaan GBHN dari roda perjalanan Bangsa Indonesia saat ini hanyalah sebagai konsekuensi dari upaya pengurangan kewenangan MPR yang sebelumnya ditempatkan sebagai lembaga tertinggi negara. Hal itu menunjukkan bahwa penghapusan GBHN tidaklah dilatarbelakangi atas suatu persoalan yang mengarah pada keberadaan GBHN itu sendiri. Apalagi kemudian bila dikaitkan dengan fakta historisnya bahwa sejak GBHN dikenal di tanah air, belum ditemukan sejumlah persoalan yang menunjukkan bahwa keberadaan GBHN itu sendiri telah membawa persoalan bagi eksistensi Bangsa Indonesia.

Harus diakui bahwa pemerintah telah melakukan upaya mengeluarkan produk hukum sebagai pengganti GBHN, yaitu melalui Undang-Undang Nomor 25 Tahun 2004, maka lahirlah Undang-Undang Nomor 17 Tahun 2007 Tentang Rencana Pembangunan Jangka Panjang Nasional (RPJPN). Undang-Undang ini memiliki bangunan yang hampir sama dengan GBHN. Namun persoalannya kemudian adalah bahwa RPJPN lahir pada masa otonomi daerah di mana daerah memiliki keleluasaan dalam membangun daerahnya sesuai dengan potensi dan kemampuan daerah masing-masing serta hanya dituangkan dalam bentuk undang-undang. Atas dasar penerapan otonomi daerah itu pula, maka tidak tertutup kemungkinan bahwa masing-masing daerah justru membentuk Rencana Pembangunan Jangka Menengah Daerah (RPJMD) sesuai dengan versi masing-masing. Bahkan bisa jadi, istilah yang

Copyright @ C 2016, LITIGASI, p-ISSN: 0853-7100; e-ISSN: 2442-2274 
dipergunakanpun hanya didasarkan pada keinginan dan kehendak daerah masingmasing.

Seandainya GBHN masih berlaku, maka tentunya dapat dipastikan bahwa baik presiden, gubernur maupun bupati dan wali kota akan membentuk RPJMN dan RPJMD yang mengacu pada GBHN sebagai haluan negara. Dengan mendasarkan pandangan pada uraian tersebut, tulisan ini akan membahas bagaimana sesungguhnya urgensi keberadaan Garis-Garis Besar Haluan Negara (GBHN) dalam sistem ketatanegaraan Republik Indonesia.

\section{PEMBAHASAN}

\section{A. GBHN dalam Perspektif Teori}

Sebelum menjawab persoalan tentang urgensi keberadaan Garis-Garis Besar Haluan Negara (GBHN) dalam sistem ketatanegaraan Republik Indonesia, maka terdapat beberapa teori yang relevan untuk dijadikan sebagai bahan rujukan dan gambaran serta landasan secara teoritis bagi pembahasan persoalan dimaksud. Beberapa teori yang relevan dengan permasalahan keberadaan GBHN dalam sistem ketatanegaraan Republik Indonesia adalah sebagai berikut:

\section{Teori Pemisahan Kekuasaan (Trias Politika)}

Teori pemisahan kekuasaan pertama sekali dipelopori oleh Montesquieu yang kemudian lebih populer dengan doktrin "Trias Politika". Montesquieu melakukan pemisahan kekuasaan negara dalam 3 cabang kekuasaan, yaitu: pertama, kekuasaan membentuk undang-undang (legislative); kedua, kekuasaan

Copyright @ 2016 , LITIGASI, p-ISSN: 0853-7100; e-ISSN: 2442-2274 
Available online at: http://ejournal.unpas.ac.id/index.php/litigasi

Litigasi, Vol. 17(2), 2016, 3427 - 3466

DOI: http://dx.doi.org/10.23969/litigasi.v17i2.143

melaksanakan undang-undang (eksekutive) dan ketiga, kekuasaan yudikatif yang dijalankan oleh lembaga peradilan (Lomi Librayanto, 2008:19). Montesquieu berpandangan bahwa bila kekuasaan negara tidak dibatasi dengan cara melakukan pemisahan antara satu lembaga negara dengan lembaga lainnya, maka akan berpeluang untuk melahirkan perbuatan dan tindakan sewenang-wenang dari penguasa. Pandangan Montesqieu mengisyaratkan bahwa ketiga fungsi kekuasaan Negara itu harus dilembagakan dalam tiga organ negara yang mana antara satu dengan lembaga negara lainnya hanya diperkenankan menjalankan satu fungsi dan tidak diperkenankan mencampuri urusan masing-masing dalam arti yang mutlak (Jimly Asshiddiqie, 2010:31).

Namun demikian, konsep pemisahan kekuasaan hanyalah bersifat suplemen karena masing-masing kekuasaan tetap menjalankan tugas pokoknya masing-masing. Konkritnya dapat digambarkan pada penerapan prinsip "checks and balance" sebagaimana yang dipraktekkan di Amerika Serikat. Fungsi pokok Senat di Amerika Serikat adalah membentuk undang-undang, namun disamping itu Senat juga memiliki kekuasaan lain untuk melakukan "impeachment", tetapi hal itu bukan berarti merubah fungi pokoknya. Demikian juga sebaliknya, fungsi pokok Presiden Amerika Serikat tidak mengalami perubahan kendati juga berhak untuk melakukan veto terhadap rancangan undang-undang yang telah disetujui oleh Kongres (Abdul Rasyid, 2006:284-285).

Hal yang sama juga terjadi di Indonesia, dalam bidang-bidang tertentu ada kalanya di antara cabang kekuasaan saling melakukan kerjasama. Sebagai contoh

Copyright $\odot$ 2016, LITIGASI, p-ISSN: 0853-7100; e-ISSN: 2442-2274 
Available online at: http://ejournal.unpas.ac.id/index.php/litigasi

Litigasi, Vol. 17(2), 2016, 3427 - 3466

DOI: http://dx.doi.org/10.23969/litigasi.v17i2.143

adalah hubungan antara Presiden dan DPR yang mana di antara kedua lembaga negara memiliki kekuasaan yang sama dalam membentuk undang-undang dalam rangka menetapkan Anggaran Pendapatan dan Belanja Negara (APBN). Dalam perkembangan selanjutnya, khususnya dalam era demokrasi modern banyak negara dengan sistem demokrasi tidak lagi menjalankan sistem pemisahan kekuasaan secara murni sebagaimana yang dipelopori Montesqieu. Model pemisahan kekuasaan secara murni berpeluang untuk melahirkan bentuk kesewenang-wenangan di dalam lingkungan masing-masing lembaga negara. Hal ini menunjukkan bahwa tidak selamanya teori pemisahan kekuasaan akan mampu menciptakan pemerintahan yang adil.

Oleh karena itu, maka menjadi suatu kelaziman ketika berbagai negara di dunia berusaha untuk menerjemahkan teori pemisahan kekuasaan berdasarkan kebutuhan masing-masing. Penerapan prinsip teori pemisahan kekuasaan tidak selamanya sama antara negara yang satu dengan negara lainnya. Kendati ditemukan penegasan terkait dengan sistem pemisahan kekuasaan di dalam konstitusi berbagai negara, namun dalam praktiknya bahwa konsep pemisahan kekuasaan lebih didasarkan pada kebutuhan masing-masing negara.

Berdasarkan apa yang diuraikan di atas, maka dapat dipahami bahwa keberadaan teori pemisahan kekuasaan sangat penting dalam rangka membahas urgensi keberadaan GBHN dalam sistem ketatanegaraan Republik Indonesia. Keberadaan GBHN yang sejak awal diatur dalam konstitusi dan kemudian kewenangan pembentukannya diserahi kepada MPR sebagai salah satu lembaga

Copyright @ 2016 , LITIGASI, p-ISSN: 0853-7100; e-ISSN: 2442-2274 
Available online at: http://ejournal.unpas.ac.id/index.php/litigasi

Litigasi, Vol. 17(2), 2016, 3427 - 3466

DOI: http://dx.doi.org/10.23969/litigasi.v17i2.143

negara yang lebih merepresentasikan pelaksana cabang kekuasaan legislatif cukup menunjukkan betapa teori pemisahan kekuasaan sangat berperan penting dalam mengulas persoalan ini.

\section{Teori Negara Hukum}

Selain teori pemisahan kekuasaan, teori negara hukum juga relevan diterapkan dalam mengulas masalah keberadaan GBHN. Konsepsi pemikiran tentang negara hukum sudah muncul jauh sebelum terjadinya Revolusi 1688 di Inggris, namun dalam perjalanannya baru muncul kembali pada abad ke XVII dan mulai populer pada abad ke XIX (Ni'matul Huda, 2005:1). Lahirnya pemikiran tentang negara hukum adalah merupakan reaksi atas tindakan sewenang-wenang yang dilakukan penguasa ketika itu. Oleh karena itu maka pembatasan kekuasaan penguasa perlu dilakukan melalui perangkat hukum agar pemerintahan dapat terkendali dengan baik. Cita negara hukum untuk pertama kalinya dikemukakan oleh seorang filosof Yunani bernama Plato. Dalam bukunya yang berjudul Nomoi, Plato menggambarkan bagaimana pentingnya posisi hukum dalam mengatur negara. Bahkan Plato menyatakan bahwa penyelanggaraan pemerintahan yang baik adalah yang diatur oleh hukum.

Awalnya, Plato dalam bukunya berjudul Republic, menginginkan agar negara diperintah oleh seorang raja filosof dengan harapan bahwa negara akan dapat diperintah secara bijak tanpa harus tunduk pada aturan hukum (Munir Fuady, 2009:27). Kemudian pemikiran Plato dikembangkan oleh muridnya yang bernama Aristoteles. Dalam pandangannya, Aristoteles berusaha mewariskan

Copyright @ 2016 , LITIGASI, p-ISSN: 0853-7100; e-ISSN: 2442-2274 
Available online at: http://ejournal.unpas.ac.id/index.php/litigasi

Litigasi, Vol. 17(2), 2016, 3427 - 3466

DOI: http://dx.doi.org/10.23969/litigasi.v17i2.143

ajaran gurunya dengan melakukan penyempurnaan terhadap pengertian negara hukum. Aristoteles mengatakan bahwa suatu negara yang baik adalah negara yang diperintah dengan konstitusi dan berkedaulatan hukum (Iriyanto A Baso Ence, 2008:32). Menurut Aristoteles, sesungguhnya yang memerintah dalam negara bukanlah manusia, melainkan pikiran yang adil dan kesusilaan berperan guna menentukan baik buruknya suatu hukum. Manusia harus dididik menjadi warga negara yang baik dan ber-asusila, dengan demikian maka manusia akan ditempa menjadi warga negara yang bersikap adil. Adapun Immanuel Kant (Nukthoh Arfawie Kurde, 2005:17) menggambarkan negara hukum sebagai penjaga malam, artinya bahwa tugas negara hanya menjaga hak-hak rakyat. Namun demikian, gagasan ini tentunya masih mengandung kelemahan, karena dalam praktik ada kalanya negara tidak hanya bertugas menjaga dan melindungi hak-hak rakyat, namun harus turut campur tangan dan kondisi dan hal-hal tertentu.

Dari pandangan Aristoteles itu dapat dipahami bahwa negara hukum memiliki keterkaitan yang sangat erat dengan keadilan dan konstitusi. Oleh sebab itulah, maka berbagai negara, termasuk Indonesia menempatkan pengaturan konsepsi negara hukum dalam konstitusinya. Hal ini dilakukan agar penegasan konsep negara hukum dapat terpatri dalam kehidupan kenegaraan dan menjadi landasan yang sangat kuat dalam menjalankan roda pemerintahan dan kehidupan bernegara.

Dalam perjalanannya, konsep negara hukum sering diterjemahkan dengan berbagai istilah yang berbeda-beda. Di negara-negara Eropa Continental, konsep

Copyright @ C 2016, LITIGASI, p-ISSN: 0853-7100; e-ISSN: 2442-2274 
Available online at: http://ejournal.unpas.ac.id/index.php/litigasi

Litigasi, Vol. 17(2), 2016, 3427 - 3466

DOI: http://dx.doi.org/10.23969/litigasi.v17i2.143

negara hukum disebut dengan istilah rechtsstaat. Istilah rechtsstaat adalah merupakan bahasa Belanda yang memiliki makna dan pengertian sejajar dengan rule of law di negara-negara yang menganut sistem Anglo Saxon (Munir Fuady, 2009:2). Di Indonesia dikenal dengan istilah "negara hukum", yang dalam bahasa Jerman disebut dengan istilah "rechtsstaat" atau dalam bahasa Perancis disebut dengan istilah "Etat de Droit" dan istilah "Stato di Diritto" dalam bahasan Italia. Dicey (Munir Fuady, 2009:2-4) menyebutkan bahwa ada 3 (tiga) arti dari negara hukum dalam arti rule of law, yaitu:

a. Supremasi absolut ada pada hukum, bukan pada tindakan kebijaksanaan atau prerogatif penguasa;

b. Berlakunya prinsip persamaan dimuka hukum (equility before the law), dimana semua orang harus tunduk kepada hukum dan tidak seorangpun yang berada diatas hukum (above the law);

c. Konstitusi merupakan dasar dari segala hukum bagi negara yang bersangkutan. Dalam hal ini, hukum yang berdasarkan konstitusi harus melarang setiap pelanggaran terhadap hak dan kemerdekaan rakyat.

Sedangkan Hans Kelsen memberikan argumentasi bahwa dalam kaitan Negara hukum yang juga merupakan Negara demokratis setidaknya harus memiliki 4 (empat) syarat rechtsstaat, yaitu:

a. Negara yang kehidupannya sejalan dengan konstitusi dan undang-undang yang proses pembuatannya dilakukan oleh parlemen;

b. Negara yang mengatur mekanisme pertanggungjawaban atas setiap kebijakan dan tindakan yang dilakukan oleh elit negara;

c. Negara yang menjamin kemerdekaan kekuasaan kehakiman;

d. Negara yang melindungi hak azasi manusia.

Kemudian terkait dengan posisi norma hukum dalam sebuah negara, Hans Kelsen menjelaskan bahwa norma-norma konstitusi yang mengatur pembentukan norma-norma umum yang harus diterapkan oleh pengadilan dan organ-organ

Copyright @ C 2016, LITIGASI, p-ISSN: 0853-7100; e-ISSN: 2442-2274 
Available online at: http://ejournal.unpas.ac.id/index.php/litigasi

Litigasi, Vol. 17(2), 2016, 3427 - 3466

DOI: http://dx.doi.org/10.23969/litigasi.v17i2.143

penegak hukum lainnya bukanlah norma-norma yang lengkap dan berdiri sendiri. Norma itu bagian intrinsik dari segenap norma hukum yang harus diterapkan oleh pengadilan dan organ-organ penegak hukum lainnya. Atas dasar itulah, maka konstitusi tidak dapat disebut sebagai satu contoh norma hukum yang tidak mempunyai sanksi (Hans Kelsen, 1973). Pandangan Hans Kelsen itu setidaknya semakin menguatkan pemaknaan negara hukum khususnya pengertian konstitusi yang tidak dapat dimaknai hanya sebatas pengaturan hal-hal umum dan abstrak dalam kehidupan bernegara.

Friedrich Julius Stahl (Munir Fuady, 2009:27), seorang sarjana hukum Jerman menjelaskan bahwa suatu Negara hukum formal harus memenuhi persyaratan sebagai berikut:

a. Adanya pengakuan terhadap hak-hak asasi manusia;

b. Adanya pemisahan kekuasaan;

c. Pemerintah dijalankan berdasarkan kepada undang-undang (hukum tertulis);

d. Adanya pengadilan administrasi.

Pada prinsipnya, kendati ditemukan beberapa perbedaan istilah dan pengertian serta ciri-ciri terkait dengan negara hukum, namun dari keseluruhan pandangan yang ada selalu berusaha menegaskan bahwa negara hukum adalah negara yang melandaskan setiap kehidupan kenegaraannya didasarkan pada mekanisme hukum yang jelas. Dengan demikian, maka upaya menciptakan negara hukum yang demokratis (democratise rechtsstaat) akan dapat diwujudnyatakan. Oleh sebab itu, maka Indonesia sebagai negara hukum yang telah ditegaskan dalam ketentuan Pasal 1 ayat (3) UUD NRI 1945 sepenuhnya harus 
Available online at: http://ejournal.unpas.ac.id/index.php/litigasi

Litigasi, Vol. 17(2), 2016, 3427 - 3466

DOI: http://dx.doi.org/10.23969/litigasi.v17i2.143

menjalankan roda pemerintahan berdasarkan ketentuan hukum yang telah digariskan dalam konstitusi.

Negara hukum menghendaki segala lini kehidupan berbangsa dan bernegara, terlebih menyangkut pelaksanaan roda pemerintahan haruslah didasarkan pada mekanisme hukum yang berlaku. Kemudian bila dikaitkan dengan kondisi Bangsa Indonesia, keberadaan UUD NRI Tahun 1945 sebagai hukum dasar negara yang kemudian sebelum amandemen memuat keberadaan GBHN sebagai haluan negara cukup mencerminkan bahwa segala ketentuan dalam UUD NRI Tahun 1945, termasuk berbagai ketentuan yang diatur dalam GBHN haruslah dijalankan dan diwujudnyatakan sebagai konsekuensi dari negara hukum. Dengan demikian, maka kiranya tepatlah menjadikan teori negara hukum sebagai salah satu landasan teori dalam membahas keberadaan GBHN dalam sistem ketatanegaraan Republik Indonesia.

B. GBHN dalam Perspektif Historis dan Yuridis

Menurut Ketetapan MPR Nomor IV/MPR/1999 Tentang Garis-Garis Besar Haluan Negara Tahun 1999-2004 bahwa yang dimaksud dengan GarisGaris Besar Haluan Negara adalah haluan negara tentang penyelenggaraan negara dalam garis-garis besar sebagai pernyataan kehendak rakyat secara menyeluruh dan terpadu yang ditetapkan oleh Majelis Permusyawaratan Rakyat untuk lima tahun guna mewujudkan kesejahteraan rakyat yang berkeadilan. Deddy Supriady Bratakusumah (2003) menyebutkan bahwa GBHN adalah merupakan pernyataan

Copyright @ 2016 , LITIGASI, p-ISSN: 0853-7100; e-ISSN: 2442-2274 
Available online at: http://ejournal.unpas.ac.id/index.php/litigasi

Litigasi, Vol. 17(2), 2016, 3427 - 3466

DOI: http://dx.doi.org/10.23969/litigasi.v17i2.143

keinginan rakyat yang menjadi acuan utama atas seluruh kiprah kenegaraan dalam mewujudkan cita-cita berbangsa dan bernegara sebagaimana secara eksplisit dituangkan dalam pembukaan UUD NRI Tahun 1945.

Maksud dan tujuan ditetapkannya Garis-Garis Besar Haluan Negara adalah dalam rangka memberikan arah penyelenggaraan negara dengan tujuan menwujudkan kehidupan yang demokratis, berkeadilan sosial, melindungi hak asasi manusia, menegakkan supremasi hukum dalam tatanan masyarakat dan bangsa yang beradab, berakhlak mulia, mandiri, bebas, maju dan sejahtera untuk kurun waktu lima tahun ke depan. Dalam perjalanan sejarahnya, GBHN ditetapkan oleh MPR untuk jangka waktu tertentu, yaitu 5 tahun. Kewenangan pembentukan GBHN oleh MPR didasarkan pada ketentuan Pasal 3 UUD 1945 sebelum amandemen. Langkah pembentukan GBHN sejak awal dimaksudkan dalam rangka memberikan arah yang jelas bagi roda perjalanan bangsa selama lima tahun ke depan. Dengan demikian, maka dapat dipahami bahwa GBHN menjadi penunjuk arah perjalanan bangsa sesuai dengan apa yang diinginkan oleh rakyat, khususnya keinginan para pihak yang berkompeten di dalam pembentukannya.

Mengingat bahwa GBHN ditetapkan oleh MPR, maka sudah barang tentu bahwa substansi yang terkandung dalam GBHN tidak terlepas dari unsur politik yang mengemuka pada saat penetapannya. Namun demikian, unsur politik yang terkandung dalam GBHN tidaklah terselubung, melainkan dilakukan secara resmi dan penuh dengan prinsip transparansi oleh MPR karena semua organ negara dan

Copyright @ 2016 , LITIGASI, p-ISSN: 0853-7100; e-ISSN: 2442-2274 
Available online at: http://ejournal.unpas.ac.id/index.php/litigasi

Litigasi, Vol. 17(2), 2016, 3427 - 3466

DOI: http://dx.doi.org/10.23969/litigasi.v17i2.143

semua lapisan masyarakat, serta dunia internasional dapat mengakses, membaca dan memahami bagaimana sesungguhnya kondisi bangsa Indonesia dari masa ke masa (M.Solly Lubis, 2010:2).

Dalam perjalanan historisnya, khususnya selama tampuk kekuasaan berada dalam kendali pemerintahan orde baru, setidaknya MPR telah berupaya menjalankan tugas dan tanggungjawabnya dalam bidang penetapan GBHN. Selama kurun waktu orde baru, MPR telah menetapkan 6 GBHN, mulai dari GBHN Tahun 1973, GBHN Tahun 1978, GBHN Tahun 1983, GBHN Tahun 1988, GBHN Tahun 1993 dan GBHN Tahun 1998. Penetapan GBHN ketika itu dilakukan secara berkesinambungan dan berkelanjutan dalam setiap periode 5 tahun sekali. Sekalipun terjadi pergantian konstitusi beberapa kali pada masa orde baru, namun aspek ideologi dan tujuan pembangunan nasional tidak serta merta mengalami perubahan (M.Solly Lubis, 2009:49).

Dalam perjalanannya, seluruh GBHN yang ditetapkan pada masa orde baru diformat dengan bentuk rumusan yang sama, khususnya dalam hal Tujuan Pembangunan Nasional. Adapun format kesamaan rumusan dimaksud adalah :

Pembangunan Nasional bertujuan untuk mewujudkan suatu masyarakat yang adil dan makmur baik materiil maupun spirituil dengan berdasarkan Pancasila di dalam wadah Negara Kesatuan Republik Indonesia (NKRI) yang merdeka, berdaulat dan bersatu dalam suasana peri kehidupan bangsa dan negara yang aman, tenteram, tertib dan dinamis serta dalam lingkungan pergaulan dunia yang merdeka, bersahabat, tertib dan damai.

Adapun GBHN yang ditetapkan dalam bentuk TAP MPR selama orde baru adalah TAP MPR No. IV/MPR/1973, TAP MPR No. IV/MPR/1978, TAP

Copyright @ C 2016, LITIGASI, p-ISSN: 0853-7100; e-ISSN: 2442-2274 
MPR No.II/MPR/1983, TAP MPR No. II/MPR/1988, TAP MPR No. II/MPR/1993, dan TAP MPR No. II/MPR/1998. Kemudian dalam perjalanan berikutnya, yaitu seiring dengan terjadinya reformasi pada tahun 1998, maka seiring dengan itu pula telah terjadi perpindahan kekuasaan dari era orde baru menuju era reformasi. Pada awal reformasi, MPR melalui sidang umum MPR tanggal 19 Oktober 1999 telah berhasil menetapkan TAP MPR Nomor IV/MPR/1999 Tentang Garis-Garis Besar Haluan Negara (GBHN) Tahun 19992004. Adapun maksud dan tujuan ditetapkannya GBHN kali ini adalah dalam rangka memberikan arah penyelenggaraan negara dengan tujuan mewujudkan kehidupan yang demokratis, berkeadilan sosial, melindungi hak asasi manusia, menegakkan supremasi hukum dalam tatanan masyarakat dan bangsa yang beradab, berakhlak mulia, mandiri, bebas, maju dan sejahtera untuk kurun waktu lima tahun ke depan.

Bila kemudian dibandingkan dengan GBHN sebelumnya, maka terdapat perbedaan dari segi tujuan GBHN itu sendiri. GBHN pada tahun 1999 lebih diarahkan dalam rangka membangun suasana kehidupan yang demokratis, berkeadilan serta mampu menegakkan hak asasi manusia dan penegakan supremasi hukum yang mencerminkan nilai-nilai keadilan. Adanya perbedaan atau barangkali lebih tepat disebut sebagai pergeseran tujuan ini adalah dikarenakan kondisi yang ada saat itu, yaitu pada awal reformasi, di mana seluruh elemen masyarakat menghendaki adanya perubahan mendasar dalam pola kehidupan berbangsa dan bernegara di Indonesia.

Copyright $\odot$ 2016, LITIGASI, p-ISSN: 0853-7100; e-ISSN: 2442-2274 
Available online at: http://ejournal.unpas.ac.id/index.php/litigasi

Litigasi, Vol. 17(2), 2016, 3427 - 3466

DOI: http://dx.doi.org/10.23969/litigasi.v17i2.143

Tentunya pergeseran tujuan GBHN itu tidaklah perlu diperdebatkan, karena bagaimanapun, secara keseluruhan tujuan GBHN dialamatkan dalam rangka mewujudkan Bangsa Indonesia yang berkeadilan dan berkemakmuran. Berdasarkan uraian di atas, maka dalam perspektif historis dapat disimpulkan bahwa keberadaan GBHN sangatlah urgen bagi Bangsa Indonesia. GBHN telah menunjukkan jati dirinya sebagai haluan negara berdasarkan catatan sejarah. Oleh sebab itu, maka upaya menghidupan atau mengembalikan keberadaan GBHN dalam perspektif sejarah sangatlah beralasan, karena memang sangat memiliki makna dan arti penting bagi Bangsa Indonesia.

Selanjutnya dalam perspektif yuridis, GBHN juga memiliki tingkat urgensitas yang memadai. Penempatan GBHN dalam bentuk produk hukum yang bernama Ketetapan MPR bukanlah sebatas memberikan label hukum bagi TAP MPR. Dalam perspektif yuridis, GBHN yang kemudian dituangkan dalam bentuk TAP MPR patut dimaknai dalam rangka menguatkan kedudukan MPR sebagai salah satu lembaga negara. Artinya bahwa secara yuridis formal, GBHN yang ditetapkan dalam TAP MPR bukanlah semata-mata hanya sekadar alat penunjuk atau kompas maupun haluan bagi Bangsa Indonesia, melainkan bahwa keberadaannya akan turut membangun kekuatan bagi posisi dan keberadaan serta eksistensi MPR sebagai salah satu lembaga negara di masa mendatang.

Dengan demikian, maka secara yuridis formal bahwa keberadaan GBHN akan membawa dampak dan arti yang bersifat multifungsi. Di samping tertatanya dan terencananya haluan negara secara berkesinambungan (GBHN ditetapkan

Copyright @ 2016 , LITIGASI, p-ISSN: 0853-7100; e-ISSN: 2442-2274 
Available online at: http://ejournal.unpas.ac.id/index.php/litigasi

Litigasi, Vol. 17(2), 2016, 3427 - 3466

DOI: http://dx.doi.org/10.23969/litigasi.v17i2.143

setiap lima tahun), GBHN juga membawa dampak positif bagi keberlangsungan dan masa depan MPR sebagai salah satu lembaga negara yang posisi dan derajatnya sama dengan lembaga-lembaga negara lainnya. Dengan demikian, maka mengembalikan keberadaan GBHN dalam posisi semula sama artinya menguatkan kembali keberadaan MPR sebagai salah satu lembaga negara.

Penguatan kedudukan dan keberadaan MPR melalui pemberian kewenangan penetapan GBHN bukanlah dengan maksud untuk mengembalikan format kelembagaan MPR pada masa lalu, yaitu sebagai lembaga tertinggi negara, melainkan harus dimaknai dalam rangka membangun eksistensi MPR di masa yang akan datang. Pemahaman ini harus diluruskan dan ditekankan agar tidak muncul suatu opini keliru yang kemudian dapat menghambat upaya menghidupkan keberadaan GBHN di masa yang akan datang.

\section{Urgensi Keberadaan GBHN Sebagai Petunjuk dan Arah Penyelenggaraan Negara}

Adalah merupakan hal yang umum bahwa dalam setiap organisasi, baik dalam skala kecil maupun besar selalu membutuhkan yang namanya perencanaan. Hal yang sama tentunya juga berlaku bagi negara sebagai sebuah organisasi. Ketika suatu organisasi (termasuk negara) tidak dilandasi pada pola dan konsep perencanaan yang matang, jelas, terukur dan terencana sedemikian rupa, maka hampir dapat dipastikan bahwa arah perjalanan maupun masa depannya akan patut dipertanyakan. Karena akan sulit kemudian untuk menentukan langkah

Copyright $\odot$ 2016, LITIGASI, p-ISSN: 0853-7100; e-ISSN: 2442-2274 
Available online at: http://ejournal.unpas.ac.id/index.php/litigasi

Litigasi, Vol. 17(2), 2016, 3427 - 3466

DOI: http://dx.doi.org/10.23969/litigasi.v17i2.143

tindak lanjut yang hendak dilakukan, termasuk kesulitan dalam rangka mengukur berhasil tidaknya misi sebuah organisasi.

Kemudian dalam rangka mengakomodir berbagai perkembangan yang ada, maka tentunya perencanaan itu diharapkan harus mampu menyentuh persoalanpersoalan aktual yang kemudian hal itu akan tergambar dari sejauh mana langkah perubahan yang dilakukan terhadap perencanaan-perencanaan yang ditawarkan. Artinya bahwa setiap perencanaan itu harus selalu di-update sesuai dengan tingkat perkembangan jaman dan tingkat tuntutan kebutuhan yang ada.

Dalam hal perencanaan suatu negara, khususnya Indonesia, sistem perencanaan yang dibangun haruslah mampu menjangkau apa-apa saja yang menjadi kebutuhan negara dan warganya dengan melakukan perubahan terhadap perencanaan yang ada secara periodik. Dengan demikian, maka langkah untuk menggapai tujuan negara secara berkesinambungan akan dapat direalisasikan. Kendati tuntutan kebutuhan suatu negara tidaklah sama dari waktu ke waktu, namun hal itu harus dipahami sebagai bentuk langkah update dari tujuan pokok yang hendak dicapai. Artinya bahwa sudah terdapat suatu kesepakatan awal yang menjadi tujuan umum yang hendak dicapai yang kemudian akan berlaku dalam jangka waktu yang cukup lama, bahkan berlaku sampai selama-lamanya. Kalaupun ditemukan penjabaran lebih rinci yang selalu membutuhkan langkah pemutakhiran, hal itu tidaklah boleh menyimpangi tujuan pokok yang telah digariskan sebelumnya.

Copyright @ C 2016, LITIGASI, p-ISSN: 0853-7100; e-ISSN: 2442-2274 
Available online at: http://ejournal.unpas.ac.id/index.php/litigasi

Litigasi, Vol. 17(2), 2016, 3427 - 3466

DOI: http://dx.doi.org/10.23969/litigasi.v17i2.143

Bagi Bangsa Indonesia, tujuan umum sekaligus tujuan pokok yang sudah digariskan sejak bangsa ini merdeka dan kemudian berlaku hingga detik ini adalah tujuan negara Republik Indonesia sebagaimana yang tertuang dalam alinea keempat Pembukaan UUD NRI Tahun 1945. Adapun bunyi alinea keempat UUD NRI Tahun 1945 adalah sebagai berikut:

"Kemudian daripada itu untuk membentuk suatu Pemerintah Negara Indonesia yang melindungi segenap bangsa Indonesia dan seluruh tumpah darah Indonesia dan untuk memajukan kesejahteraan umum, mencerdaskan kehidupan bangsa, dan ikut melaksanakan ketertiban dunia yang berdasarkan kemerdekaan, perdamaian abadi dan keadilan sosial, maka disusunlah Kemerdekaan Kebangsaan Indonesia itu dalam suatu Undang-Undang Dasar Negara Indonesia, yang terbentuk dalam suatu susunan Negara Republik Indonesia yang berkedaulatan rakyat dengan berdasar kepada Ketuhanan Yang Maha Esa, Kemanusiaan yang adil dan beradab, Persatuan Indonesia dan Kerakyatan yang dipimpin oleh hikmat kebijaksanaan dalam Permusyawaratan/Perwakilan, serta dengan mewujudkan suatu Keadilan sosial bagi seluruh rakyat Indonesia”.

Dalam rangka mewujudkan apa yang telah digariskan dalam pembukaan UUD NRI Tahun 1945 sebagai tujuan negara, maka Bangsa Indonesia telah melakukan konsep perencanaan yang matang melalui pembentukan GBHN di masa lalu. GBHN menjadi haluan dalam rangka menggiring arah perjalanan dan penyelenggaraan negara selama lima tahun ke depan. Konsep-konsep yang tertuang dalam GBHN selalu diperbaharui setiap lima tahun sekali. Konsep yang tertuang dalam GBHN itulah yang kemudian dijadikan landasan berpikir dan bertindak bagi pemerintah yang sedang berkuasa dalam rangka mewujudkan tujuan umum Bangsa Indonesia sebagaimana yang tertuang dalam Pembukaan UUD NRI Tahun 1945.

Copyright @ C 2016, LITIGASI, p-ISSN: 0853-7100; e-ISSN: 2442-2274 
Available online at: http://ejournal.unpas.ac.id/index.php/litigasi

Litigasi, Vol. 17(2), 2016, 3427 - 3466

DOI: http://dx.doi.org/10.23969/litigasi.v17i2.143

Namun kemudian setelah era reformasi, seiring dengan dilakukannya perubahan terhadap UUD NRI Tahun 1945, keberadaan GBHN justru dihilangkan. Hal ini sejalan dengan dihilangkannya ketentuan yang memberikan kewenangan kepada MPR untuk menetapkan GBHN. Sebelum dilakukan perubahan terhadap UUD NRI Tahun 1945, maka Pasal 3 berbunyi "Majelis Permusyawaratan Rakyat menetapkan Undang-Undang Dasar dan garis-garis besar daripada haluan negara".

Kemudian setelah perubahan ketiga pada tahun 2001 terhadap UUD NRI Tahun 1945, ketentuan Pasal 3 dibagi dalam tiga ayat, diantaranya:

(1) Majelis Permusyawaratan Rakyat berwenang mengubah dan menetapkan Undang-Undang Dasar.

(2) Majelis Permusyawaratan Rakyat melantik Presiden dan/atau Wakil Presiden.

(3) Majelis Permusyawaratan Rakyat hanya dapat memberhentikan Presiden dan/atau Wakil Presiden dalam masa jabatannya menurut Undang-Undang Dasar.

Dengan dihilangkannya kewenangan MPR dalam menetapkan GBHN, maka secara otomatis bahwa GBHN tidak ditemukan lagi untuk dijadikan rujukan dalam menjalankan roda pemerintahan. Adapun GBHN yang terakhir ditetapkan oleh MPR adalah GBHN Tahun 1999-2004 yang kemudian dituangkan dalam TAP MPR Nomor IV/1999 Tentang Garis-Garis Besar Haluan Negara Tahun 1999-2004. TAP MPR ini dibentuk dengan Visi untuk mewujudkan masyarakat Indonesia yang damai, demokratis, berkeadilan, berdaya saing, maju dan sejahtera dalam wadah Negara Kesatuan Republik Indonesia yang sehat, mandiri, beriman, bertaqwa, berakhlak mulia, cinta tanah air, berkesadaran hukum dan lingkungan

Copyright @ 2016, LITIGASI, p-ISSN: 0853-7100; e-ISSN: 2442-2274 
Available online at: http://ejournal.unpas.ac.id/index.php/litigasi

Litigasi, Vol. 17(2), 2016, 3427 - 3466

DOI: http://dx.doi.org/10.23969/litigasi.v17i2.143

yang menguasai ilmu pengetahuan dan teknologi serta memiliki etos kerja yang tinggi serta dibarengi dengan tingkat disiplin yang tinggi pula.

Setelah dihilangkannya GBHN yang merupakan konsekuensi dari penghapusan kewenangan MPR dalam menetapkan GBHN, maka konsep pembangunan nasional dilegalisasikan melalui pembentukan Undang-Undang Nomor 25 Tahun 2004 Tentang Sistem Perencanaan Pembangunan Nasional. Kemudian Undang-Undang ini mengamanatkan adanya suatu dokumen negara mengenai perencanaan jangka panjang bagi roda perjalanan pemerintahan di Indonesia (Prayudi, 2007:95).

Dalam rangka memenuhi amanat Undang-Undang Nomor 25 Tahun 2004, maka lahirlah Undang-Undang Nomor 17 Tahun 2007 Tentang Rencana Pembangunan Jangka Panjang Nasional (RPJPN). UU RPJPN itu sendiri lahir atas langkah yang dilakukan pemerintah yang mengajukan draft RUU Tentang RPJPN Tahun 2005-2025 kepada DPR untuk dibahas secara bersama-sama. Namun kemudian dalam praktiknya bahwa keberadaan Nomor 17 Tahun 2007, termasuk Undang-Undang Nomor 25 Tahun 2004 belumlah mampu menggantikan keberadaan GBHN sebagai arah sekaligus penunjuk bagi penyelenggaraan roda pemerintahan. Padahal, dihapuskannya GBHN merupakan landasan bagi lahirnya Undang-Undang Nomor 25 Tahun 2004 (Sumardi, 2010).

Berbagai ketentuan yang terkandung di dalamnya juga kemungkinan tidak terlepas dari berbagai bentuk kompromi politik pragmatis yang terlalu mudah

Copyright @ C 2016, LITIGASI, p-ISSN: 0853-7100; e-ISSN: 2442-2274 
Available online at: http://ejournal.unpas.ac.id/index.php/litigasi

Litigasi, Vol. 17(2), 2016, 3427 - 3466

DOI: http://dx.doi.org/10.23969/litigasi.v17i2.143

diubah kalau hanya diatur dalam tingkatan undang-undang, sehingga dikhawatirkan akan berdampak tidak efektifnya rencana-rencana pembangunan yang telah dilegalkan itu. Keberadaan perencanaan pembangunan nasional yang hanya dituangkan dalam bentuk undang-undang juga akan berpotensi untuk melahirkan pemerintahan yang minus prestasi dan bahkan tidak mampu untuk melakukan berbagai upaya dan terobosan dalam rangka membangun sistem pemerintahan yang lebih baik. Sebagaimana prosedur yang berlaku, bahwa proses pembentukan dan perubahan undang-undang jauh lebih mudah bila dibandingkan dengan TAP MPR, sehingga sangat diyakini bahwa produk hukum yang bernama undang-undang lebih sarat muatan politisnya dibandingkan dengan TAP MPR.

Belum lagi prosedur pembentukan TAP MPR yang harus melibatkan anggota DPD selain DPR. Dengan prosedur yang demikian, maka nuansa politik pragmatis dalam pembentukan undang-undang diyakini jauh lebih kuat dibanding pembentukan TAP MPR sebagai wadah hukum dalam menetapkan GBHN. Di sinilah salah satu letak urgensi keberadaan GBHN sebagai arah penyelenggaraan negara ke depan. GBHN pada masa pemberlakuannya yang berasal dari MPR dan kemudian diamanatkan kepada presiden untuk dijadikan rujukan dan pedoman dalam menjalankan roda pemerintahan sesungguhnya telah menempati posisi yang ideal bagi rencana pembangunan nasional.

Copyright @ C 2016, LITIGASI, p-ISSN: 0853-7100; e-ISSN: 2442-2274 
Available online at: http://ejournal.unpas.ac.id/index.php/litigasi

Litigasi, Vol. 17(2), 2016, 3427 - 3466

DOI: http://dx.doi.org/10.23969/litigasi.v17i2.143

\section{GBHN Memperkuat Kedudukan MPR}

Setelah dihapuskannya kewenangan MPR dalam menetapkan GBHN, maka sejak saat itu, lembaga yang satu ini seolah kehilangan sebagian besar kekuatannya dan bahkan hampir berpengaruh terhadap eksistensinya sebagai salah satu lembaga negara. Berdasarkan ketentuan Pasal 3 UUD NRI 1945 hasil amandemen, MPR memiliki dua kewenangan utama. Pertama, mengubah dan menetapkan UUD; dan kedua, melantik presiden dan atau wakil presiden. Selanjutnya, menurut ketentuan Pasal 4 Undang-Undang Nomor 27 Tahun 2009 Tentang Majelis Permusyawaratan Rakyat, Dewan Perwakilan Rakyat, Dewan Perwakilan Daerah dan Dewan Perwakilan Rakyat Daerah, MPR mempunyai tugas dan wewenang sebagai berikut:

1. mengubah dan menetapkan Undang-Undang Dasar Negara Republik Indonesia Tahun 1945;

2. melantik Presiden dan/atau Wakil Presiden hasil pemilihan umum;

3. memutuskan usul DPR untuk memberhentikan Presiden dan/atau Wakil Presiden dalam masa jabatannya, setelah Mahkamah Konstitusi memutuskan bahwa Presiden dan/atau Wakil Presiden terbukti melakukan pelanggaran hukum berupa pengkhianatan terhadap negara, korupsi, penyuapan, tindak pidana berat lainnya, atau perbuatan tercela dan/atau terbukti bahwa Presiden dan/atau Wakil Presiden tidak lagi memenuhi syarat sebagai Presiden dan/atau Wakil Presiden;

4. melantik Wakil Presiden menjadi Presiden apabila Presiden mangkat, berhenti, diberhentikan, atau tidak dapat melakukan kewajibannya dalam masa jabatannya;

5. memilih Wakil Presiden dari 2 (dua) calon yang diusulkan oleh Presiden apabila terjadi kekosongan jabatan Wakil Presiden dalam masa jabatannya; dan

6. memilih Presiden dan Wakil Presiden apabila keduanya mangkat, berhenti, diberhentikan, atau tidak dapat melakukan kewajibannya dalam masa jabatannya secara bersamaan, dari 2 (dua) pasangan calon presiden dan wakil presiden yang diusulkan oleh partai politik atau gabungan partai politik yang pasangan calon Presiden dan Wakil Presidennya meraih suara terbanyak

Copyright $\odot$ 2016, LITIGASI, p-ISSN: 0853-7100; e-ISSN: 2442-2274 
Available online at: http://ejournal.unpas.ac.id/index.php/litigasi

Litigasi, Vol. 17(2), 2016, 3427 - 3466

DOI: http://dx.doi.org/10.23969/litigasi.v17i2.143

pertama dan kedua dalam pemilihan umum sebelumnya, sampai berakhir masa jabatannya.

Dalam rangka perwujudan tugas pertama, tentunya akan sangat sulit diukur frekuensi keberlangsungannya. Masalahnya rencana dan upaya untuk melakukan perubahan terhadap UUD NRI Tahun 1945 belum tentu akan selalu muncul tiap tahun atau tiap periode. Artinya bahwa besar kemungkinan dalam satu periode masa jabatan para anggota MPR tidak akan ada perubahan terhadap UUD NRI Tahun 1945. Tentu harus diakui bahwa berdasarkan pengalaman Bangsa Indonesia, pernah terjadi perubahan terhadap UUD NRI Tahun 1945 sebanyak 4 kali dalam kurun waktu 4 tahun, yaitu tahun 1999, tahun 2000, tahun 2001, tahun 2002. Namun demikian, patut dicatat bahwa terdapat sejumlah faktor yang melatarbelakanginya yang mana kemungkinan besar faktor semacam itu a kan sangat jarang terjadi. Adapun faktor dimaksud adalah mencuatnya gerakan untuk melakukan reformasi di segala lini pemerintahan, termasuk reformasi konstitusi.

Lahirnya gerakan ini adalah tidak terlepas dari situasi dan kondisi negara dan pemerintahan yang sudah mulai jauh dari harapan menuju Negara Indonesia yang adil dan makmur. Sikap otoriter yang dipraktikkan oleh pemerintahan di bawah kendali Soeharto serta pola dan karakter kinerja birokrasi yang begitu runyam, membuat masyarakat luas terdorong untuk melakukan gerakan perubahan demi mewujudkan cita-cita perjuangan bangsa sebagaimana telah ditegaskan dalam konstitusi. Atas dasar itu, maka kemudian muncul gerakan reformasi yang selain berhasil meruntuhkan kejayaan pemerintahan orde baru di

Copyright @ 2016 , LITIGASI, p-ISSN: 0853-7100; e-ISSN: 2442-2274 
Available online at: http://ejournal.unpas.ac.id/index.php/litigasi

Litigasi, Vol. 17(2), 2016, 3427 - 3466

DOI: http://dx.doi.org/10.23969/litigasi.v17i2.143

bawah kepemimpinan Soeharto, juga turut mendorong dilakukannya reformasi konstitusi melalui perubahan demi perubahan terhadap UUD NRI Tahun 1945.

Selanjutnya untuk tugas yang kedua, yaitu melantik Presiden dan/atau Wakil Presiden dapat dipastikan bahwa MPR akan menjalankan tugas dimaksud hanya sekali untuk lima tahun yaitu seiring dengan periodesasi jabatan Presiden dan/atau Wakil Presiden, kecuali bila kemudian terjadi hal-hal di luar daripada perkiraan sebelumnya, misalnya bila Presiden dan/atau Wakil Presiden tersangkut masalah hukum yang kemudian berdampak pada proses penghentiannya dari kedudukannya sebagai Presiden dan/atau Wakil Presiden.

Tugas dan kewenangan kedua ini juga telah mengalami penyempitan kekuasaan. Sebab sebelumnya, MPR dianugerahi kewenangan untuk memilih Presiden dan Wakil Presiden sebagaimana diatur dalam Pasal 6 ayat (2) UUD NRI Tahun 1945 sebelum amandemen. Sedangkan untuk saat ini, MPR hanya melantik Presiden dan/atau Wakil Presiden, sementara yang memilih adalah rakyat secara langsung. Hal ini sejalan dengan salah satu agenda reformasi dalam bidang pematangan proses demokrasi di tanah air. Rakyat sebagai pemegang kedaulatan diserahi langsung hak untuk memilih Presiden dan Wakil Presiden secara langsung, jadi bukan lewat lembaga perwakilan.

Atas dasar pencabutan kewenangan MPR dalam memilih Presiden dan Wakil Presiden, maka praktis MPR tidak lagi berwenang untuk meminta pertanggungjawaban Presiden dan Wakil Presiden. Saat ini, Presiden dan Wakil Presiden hanya memberikan laporan pertanggungjawaban secara langsung kepada

Copyright $\odot$ 2016, LITIGASI, p-ISSN: 0853-7100; e-ISSN: 2442-2274 
Available online at: http://ejournal.unpas.ac.id/index.php/litigasi

Litigasi, Vol. 17(2), 2016, 3427 - 3466

DOI: http://dx.doi.org/10.23969/litigasi.v17i2.143

rakyat yang kemudian disaksikan oleh MPR. Konsekuensi laporan pertanggungjawaban dengan model yang demikian juga tidak begitu berdampak secara yuridis. Dampak konkritnya hanya akan terlihat secara politis, yaitu bila kemudian rakyat memandang bahwa Presiden dan Wakil Presiden tidak berhasil menjalankan programnya, maka konsekuensi yang mungkin muncul adalah bahwa Presiden dan Wakil Presiden tidak akan mendapat kepercayaan memegang tampuk kekuasaan untuk periode berikutnya.

Salah satu wibawa dan kekuatan yang cukup berpengaruh yang dimiliki oleh MPR sebelum amandemen terhadap UUD NRI Tahun 1945 adalah terletak pada kewenangannya dalam menetapkan GBHN. Dengan kewenangan itu, maka kemudian MPR memiliki kekuatan untuk meminta pertanggungjawaban Presiden dan Wakil Presiden terkait dengan pelaksanaan roda pemerintahan apakah sudah sesuai dengan GBHN atau tidak. Kendati untuk saat ini, bila terjadi sikap penolakan MPR atas laporan pertanggungjawaban Presiden dan Wakil Presiden terkait dengan pelaksanaan roda pemerintahan tidak secara otomatis akan dapat menghentikan posisi dan kedudukan Presiden dan Wakil Presiden, namun setidaknya bila kewenangan menetapkan GBHN masih melekat pada MPR, maka hal itu akan dapat membangun sistem kelembagaan yang cukup kuat bagi MPR.

Bila kewenangan menetapkan GBHN masih melekat pada MPR, maka sangat diyakini bahwa MPR akan tetap eksis dan mempunyai kekuatan sebagai salah satu lembaga negara dalam rangka mengawal roda perjalanan pemerintahan yang lebih berwibawa dan bermartabat. MPR masih akan tetap mempunyai ruang

Copyright @ C 2016, LITIGASI, p-ISSN: 0853-7100; e-ISSN: 2442-2274 
Available online at: http://ejournal.unpas.ac.id/index.php/litigasi

Litigasi, Vol. 17(2), 2016, 3427 - 3466

DOI: http://dx.doi.org/10.23969/litigasi.v17i2.143

untuk turut serta terlibat dalam proses perjalanan roda pemerintahan, sekalipun keterlibatannya tidak membawa dampak secara signifikan bagi eksistensi pemerintah yang sedang berkuasa. Selain itu, penyerahan kembali kewenangan MPR dalam menetapkan GBHN harus dimaknai dalam rangka mengefektifkan lembaga tersebut untuk turut serta berkontribusi secara aktif bagi upaya perwujudan cita-cita bangsa Indonesia menuju negara yang berkeadilan dan berkemakmuran serta berkesejahteraan.

Dengan demikian, maka MPR tidak akan dituding lagi sebagai lembaga yang mandul dan tidak memiliki wibawa kenegaraan dalam peta kekuatan kelembagaan negara di tanah air sebagaimana yang terjadi saat ini. Sebagaimana diketahui bahwa saat ini MPR terkesan tidak memiliki kinerja dan reputasi mumpuni dan bahkan aktivitasnya seakan hanya sebatas melakukan sosialisasi 4 (empat) pilar berbangsa dan bernegara (Pancasila, UUD Negara Republik Indonesia Tahun 1945 dan Bhinneka Tunggal Ika). Oleh sebab itulah, maka kemudian menjadi dapat dipahami bahwa menghidupkan kembali GBHN, di samping dalam rangka membangun konsepsi penyelenggaraan negara yang terarah, terukur dan menyeluruh demi terwujudnya masyarakat Indonesia yang adil dan makmur sebagaimana dicita-citakan dalam Pembukaan UUD NRI Tahun 1945, juga membawa dampak positif dalam rangka penguatan kedudukan dan eksistensi MPR di masa yang akan datang.

Copyright (C) 2016, LITIGASI, p-ISSN: 0853-7100; e-ISSN: 2442-2274 
Available online at: http://ejournal.unpas.ac.id/index.php/litigasi

Litigasi, Vol. 17(2), 2016, 3427 - 3466

DOI: http://dx.doi.org/10.23969/litigasi.v17i2.143

\section{E. Menghidupkan GBHN Melalui Perubahan Kelima UUD NRI Tahun 1945}

Pentingnya keberadaan GBHN dalam sistem ketatanegaraan Republik Indonesia membuat Bangsa Indonesia harus kembali melakukan pengkajian mendalam terhadap upaya mengembalikan kewenangan MPR dalam menetapkan GBHN. Fakta telah menunjukkan bahwa sejak dihapuskannya GBHN, arah perjalanan roda pemerintahan menjadi kurang fokus dan sulit diukur tingkat keberhasilannya. Dalam praktiknya, sejak dihapuskannya GBHN, pemerintah dari masa ke masa, dari periode ke periode hanya mampu menawarkan programprogram yang sulit diukur tingkat keberhasilannya dan terkesan hanya mengandalkan program politik presiden terpilih. Sebagai konsekuensinya, maka setiap terjadi pergantian pemegang tampuk kekuasaan, maka setiap saat itu terjadi perubahan program sesuai dengan program politik presiden berikutnya.

Padahal, dalam kurun waktu pemerintahan orde baru, sederet program prioritas yang dituangkan dalam GBHN sedikit banyak telah dapat diwujudnyatakan dalam kehidupan berbangsa dan bernegara. Lihat saja misalnya konsep Trilogi Pembangunan, mulai dari stabilitas nasional yang dinamis, pertumbuhan ekonomi yang tinggi dan pemerataan pembangunan dan hasilhasilnya. Bangsa Indonesia juga pernah merasakan swasembada pangan pada masa pemerintahan orde baru. Semua itu dituangkan dalam GBHN yang lebih mudah diukur tingkat keberhasilannya. Sementara saat ini, sejumlah program yang digulirkan pemerintah seperti RPJPN, RPJM, MP3EI, jangankan untuk mengukur

Copyright $\odot$ 2016, LITIGASI, p-ISSN: 0853-7100; e-ISSN: 2442-2274 
Available online at: http://ejournal.unpas.ac.id/index.php/litigasi

Litigasi, Vol. 17(2), 2016, 3427 - 3466

DOI: http://dx.doi.org/10.23969/litigasi.v17i2.143

tingkat keberhasilannya, masalah penyebutannya saja masih banyak masyarakat yang tidak paham, apalagi sampai dengan upaya menganalisa dan memahaminya.

Di satu sisi, tidak adanya perencanaan mendalam terhadap tujuan dan langkah prioritas yang harus dilakukan oleh pemerintah sebagaimana tertuang sebelumnya dalam GBHN juga berdampak pada kurang efektifnya setiap langkah yang diambil dan dijalankan oleh pemerintah. Banyak persoalan bangsa yang pada awalnya digembor-gemborkan untuk diselesaikan secara tuntas dan menyeluruh, namun pada akhirnya justru hanya berjalan setengah-setengah dan belum optimal. Dalam situasi yang demikianlah, maka kehadiran GBHN menjadi salah satu langkah penting demi memantapkan roda perjalanan bangsa menuju cita-cita reformasi, khususnya cita-cita bangsa Indonesia sebagaimana dituangkan dalam Pembukaan UUD NRI Tahun 1945.

Sebenarnya, upaya untuk menghapus atau tetap mempertahankan kewenangan MPR untuk menetapkan GBHN dalam Rapat ke-25 Panitia Ad Hoc I Badan Pekerja MPR RI pada Kamis, 6 September 2001 adalah merupakan langkah yang sifatnya alternatif. Namun karena dalam proses pembahasan ketentuan Pasal 3 UUD NRI Tahun 1945 ternyata mayoritas suara menghendaki dihapuskannya kewenangan MPR dalam menetapkan GBHN, maka dengan sendirinya GBHN menjadi dihapuskan.

Salah satu pendapat yang mengarah pada upaya sekaligus dukungan dalam rangka menghapuskan keberadaan GBHN adalah pendapat dari Theo $L$. 
Available online at: http://ejournal.unpas.ac.id/index.php/litigasi

Litigasi, Vol. 17(2), 2016, 3427 - 3466

DOI: http://dx.doi.org/10.23969/litigasi.v17i2.143

Sambuaga dari Fraksi Partai Golkar dengan menyatakan pandangan sebagai berikut:

"Kemudian saudara ketua dan saudara-saudara sekalian yang saya hormati. Di dalam pasal ini juga terdapat beberapa event di dalam persoalan alternatif kedua terlihat Presiden dipilih secara langsung juga terdapat beberapa varian atau alternatif dalam ayat (2) tentang GBHN. Karena kita berpendapat bahwa Presiden dipilih langsung maka yang menjadi pedoman Presiden terpilih atau yang memerintah dalam melaksanakan tugastugasnya adalah pikiran-pikiran, komitmen-komitmen, janji-janjinya yang disampaikan selama kampanye yang dirumuskan dalam program sesudah menjadi Presiden. Oleh karena itu, dalam hal ini MPR tidak perlu menetapkan Garis-Garis Besar Haluan Negara seperti yang kita kerjakan sekarang ini. Sebab yang akan menjadi pedoman atau menjadi acuan bagi Presiden dalam melaksanakan tugasnya adalah semua komitmen atau menifesto politik atau platform yang dikemukakan, yang dicanangkan, yang ditawarkan kepada rakyat sebelum pemilihan umum" (MPR RI, 2010:193).

Kemudian, pandangan yang maknanya kurang lebih sama dengan

pandangan yang dikemukakan oleh Theo L. Sambuaga juga dikemukakan oleh

Lukman Hakim Saifuddin dari Fraksi Partai Persatuan Pembangunan (PPP) dengan

mengatakan:

"Jadi pada Pasal 3, fraksi kami termasuk yang menghendaki Presiden dipilih langsung sehingga dalam lembar persandingan ini mungkin bisa diawali mulai halaman empat itu. Jadi berkaitan dengan tugas, wewenang dan hak MPR maka ayat (1) itu tidak ada persoalan. Lalu ayat (2) nya itu memang ada dua alternatif. Kami memilih alternatif pertama yaitu alternatif yang berpendapat tidak perlu MPR ini memiliki tugas atau kewenangan menetapkan Garis-Garis Besar Haluan Negara. Jadi pandangan kami, ke depan MPR yang hakekatnya terdiri dari DPR dan DPD itu memang sudah tidak perlu lagi menetapkan GBHN, baik GBHN dalam pengertian GBHN huruf besar, yang selama ini untuk lima tahun itu maupun GBHN huruf kecil yang itu Haluan Negara dalam Garis-Garis Besarnya. Karena GBHN huruf kecil yang selama ini kemudian dikenal dengan Ketetapan-Ketetapan MPR itu kita berpandangan ke depan sudah tidak ada lagi Ketetapan MPR karena ketetapan itu hanya sebatas yang

Copyright @ C 2016, LITIGASI, p-ISSN: 0853-7100; e-ISSN: 2442-2274 
Available online at: http://ejournal.unpas.ac.id/index.php/litigasi

Litigasi, Vol. 17(2), 2016, 3427 - 3466

DOI: http://dx.doi.org/10.23969/litigasi.v17i2.143

bersifat penetapan, bukan pengaturan.... Jadi ke depan seperti itulah tidak ada GBHN lagi"(MPR RI, 2010: 197-198).

Pandangan yang kurang lebih sama juga mengemuka dari peserta lainnya ketika itu, diantaranya adalah pandangan yang dikemukakan oleh I Dewa Gde Palguna dari Fraksi PDI Perjuangan dengan mengatakan:

"Lalu yang kedua, mengenai MPR dalam kaitan ini dalam kewenangannya ini. Ini juga akan berakibat langsung pada cara proses pemilihan Presiden karena berkaitan dengan reduksi terhadap fungsi-fungsi MPR sendiri. Kalau misalnya pemilihannya adalah pemilihan Presiden secara langsung, maka fungsi membuat GBHN saya kira tidak ada. Praktis sesungguhnya adalah fungsinya yang masih ada adalah menetapkan dan mengubah UndangUndang Dasar 1945" (MPR RI, 2010: 200).

Atas dasar mayoritas pandangan yang mengarah pada penghapusan kewenangan MPR dalam menetapkan GBHN ketika itu, maka kemudian perdebatan seputar dihapuskan atau tidaknya ketentuan mengenai kewenangan MPR dalam menetapkan GBHN menjadi berakhir dengan kesepakatan dihapuskannya kewenangan dimaksud. Dengan demikian, maka resmilah kewenangan MPR untuk menetapkan GBHN dihapuskan yang kemudian berlaku hingga saat ini.

Terlepas dari perdebatan yang terjadi pada saat amandemen ketiga tahun 2001 UUD NRI Tahun 1945 terkait dengan perlu tidaknya kewenangan menetapkan GBHN oleh MPR, saat ini kiranya perlu dilakukan pengkajian mendalam terhadap upaya untuk menghidupkan atau memunculkan kembali GBHN dalam bingkai Negara Kesatuan Republik Indonesia. GBHN merupakan arah sekaligus kompas bagi perjalanan bangsa ke depan. Oleh karenanya, maka

Copyright @ C 2016, LITIGASI, p-ISSN: 0853-7100; e-ISSN: 2442-2274 
Available online at: http://ejournal.unpas.ac.id/index.php/litigasi

Litigasi, Vol. 17(2), 2016, 3427 - 3466

DOI: http://dx.doi.org/10.23969/litigasi.v17i2.143

keberadaannya sangatkan dibutuhkan demi membangun masa depan bangsa yang lebih terarah dan terukur.

Untuk dapat mewujudkan hal dimaksud, maka tiada jalan lain selain melakukan amandemen kelima terhadap UUD NRI Tahun 1945 dengan menghidupkan atau mengembalikan ketentuan Pasal 3 UUD NRI Tahun 1945, khususnya terkait kewenangan menetapkan GBHN. Memang saat ini, sejak dilakukannya amandemen terhadap UUD NRI Tahun 1945, proses dan mekanisme perubahan terhadap UUD NRI Tahun 1945 mengalami tingkat keketatan.

Sebelum dilakukan amandemen terhadap UUD NRI Tahun 1945, proses dan mekanisme perubahan UUD diatur dalam BAB XVI Pasal 37 ayat (1) dan (2) yang menyebutkan bahwa untuk mengubah Undang-Undang Dasar, maka sekurang-kurangnya 2/3 daripada jumlah anggota Majelis Permusyawaratan Rakyat harus hadir dan putusan diambil dengan persetujuan sekurang-kurangnya 2/3 daripada jumlah anggota yang hadir. Kemudian setelah dilakukan perubahan, maka proses dan mekanisme yang harus dilalui dalam rangka merubah UUD NRI Tahun 1945 sebagaimana diatur dalam Pasal 37 ayat (1) sampai dengan (5) adalah sebagai berikut:

(1) Usul perubahan pasal-pasal Undang-Undang Dasar dapat diagendakan dalam sidang Majelis Permusyawaratan Rakyat apabila diajukan oleh sekurangkurangnya $1 / 3$ dari jumlah anggota Majelis Permusyawaratan Rakyat.

(2) Setiap usul perubahan pasal-pasal Undang-Undang Dasar diajukan secara tertulis dan ditunjukkan dengan jelas bagian yang diusulkan untuk diubah beserta alasannya.

Copyright @ 2016, LITIGASI, p-ISSN: 0853-7100; e-ISSN: 2442-2274 
Available online at: http://ejournal.unpas.ac.id/index.php/litigasi

Litigasi, Vol. 17(2), 2016, 3427 - 3466

DOI: http://dx.doi.org/10.23969/litigasi.v17i2.143

(3) Untuk mengubah pasal-pasal Undang-Undang Dasar, Sidang Majelis Permusyawaratan Rakyat dihadiri oleh sekurang-kurangnya 2/3 dari jumlah anggota Majelis Permusyawaratan Rakyat.

(4) Putusan untuk mengubah pasal-pasal Undang-Undang Dasar dilakukan dengan persetujuan sekurang-kurangnya lima puluh persen ditambah satu anggota dari seluruh anggota Majelis Permusyawaratan Rakyat.

(5) Khusus mengenai bentuk Negara Kesatuan Republik Indonesia tidak dapat dilakukan perubahan.

Kendati memang bahwa secara umum terjadi peningkatan keketatan dalam rangka melakukan perubahan terhadap UUD NRI Tahun 1945 setelah amandemen, namun hal itu bukanlah suatu penghalang dalam rangka mengembalikan kewenangan MPR dalam hal menetapkan GBHN. Karena urgensi keberadaan GBHN bagi Bangsa Indonesia jauh lebih penting daripada sekadar hambatan yang akan dihadapi dalam rangka melewati mekanisme perubahan yang diatur dalam UUD NRI Tahun 1945. Tinggal persoalan kemudian adalah sejauh mana kemauan politik para anggota MPR dalam rangka melakukan perubahan dimaksud. Namun dengan melihat fakta bahwa upaya mengembalikan kewenangan MPR dalam menetapkan GBHN adalah juga merupakan bagian dari upaya menguatkan kedudukan dan keberadaan serta eksistensi MPR sebagai salah satu lembaga negara, maka sangat terbuka peluang di mana MPR sendiri akan dengan terbuka untuk membangun gerakan politik dan menggalang kekuatan sedini mungkin dalam rangka mengembalikan kewenangan menetapkan GBHN yang sudah sempat dihapuskan itu.

Copyright @ 2016 , LITIGASI, p-ISSN: 0853-7100; e-ISSN: 2442-2274 


\section{SIMPULAN DAN SARAN}

\section{A. Simpulan}

Dalam rangka membangun konsepsi penyelenggaraan negara yang terarah, terukur dan menyeluruh demi terwujudnya masyarakat Indonesia yang adil dan makmur sebagaimana dicita-citakan dalam Pembukaan UUD NRI Tahun 1945, maka keberadaan GBHN menjadi sangat urgen untuk dihidupkan kembali. GBHN adalah merupakan penunjuk arah bagi penyelenggaraan roda pemerintahan di masa depan. Di samping itu, upaya mengembalikan keberadaan GBHN juga akan berdampak positif pada upaya menjaga dan mengawal eksistensi MPR sebagai salah satu lembaga negara yang mempunyai keterkaitan melalui kewenangannya itu dengan lembaga negara lainnya.

\section{B. Saran}

Mengingat urgensi keberadaan GBHN dalam sistem ketatanegaraan Republik Indonesia, maka diharapkan agar dilakukan amandemen terhadap UUD NRI Tahun 1945, karena kewenangan MPR untuk menetapkan GBHN sebagaimana sebelumnya diatur dalam Pasal 3 hanya akan dapat dikembalikan melalui proses perubahan terhadap UUD NRI Tahun 1945. Sekalipun belakangan muncul sejumlah upaya yang mulai mempertanyakan keberadaan MPR mengingat tugas dan kewenangannya yang begitu minim, namun dalam perspektif dan keberadaan GBHN, MPR menjadi sangat dibutuhkan dan perlu dikembalikan

Copyright $\odot$ 2016, LITIGASI, p-ISSN: 0853-7100; e-ISSN: 2442-2274 
pada kedudukan semula sebagaimana layaknya kedudukan MPR sebelum perubahan UUD NRI Tahun 1945.

\section{DAFTAR PUSTAKA}

\section{BUKU}

Abdul Rasyid. 2006, Wewenang Mahkamah Konstitusi dan Implikasinya dalam Sistem Ketatanegaraan Republik Indonesia, Bandung, Citra Aditya Bakti.

CF Strong OBE. 1952, Modern Political Constitution, Sidgewick and Jackson, Limited London.

Haposan Siallagan dan Janpatar Simamora. 2011, Hukum Tata Negara Indonesia, Medan, UD. Sabar.

Hans Kelsen. 1973, General Theory of Law and State, dialihbahasakan oleh Somardi, 2007, Teori Hukum dan Negara: Dasar-Dasar IImu Hukum Normatif Sebagai Ilmu Hukum Deskriptif Empirik, Jakarta, Bee Media Indonesia.

Iriyanto A Baso Ance. 2008, Negara Hukum dan Hak Uji Konstitusionalitas Mahkamah Konstitusi: Telaah Terhadap Kewenangan Mahkamah Konstitusi, Bandung, Alumni.

Jimly Asshiddiqie. 2010, Perkembangan dan Konsolidasi Lembaga Negara Pasca Reformasi, Edisi Kedua Cetakan Pertama, Jakarta, Sinar Grafika.

M.Solly Lubis, 2009, Ilmu Pengetahuan Perundang-undangan, Bandung, Mandar Maju.

Munir Fuady. 2009, Teori Negara Hukum Modern (Rechtstaat), Bandung, Refika Aditama.

Ni'matul Huda. 2005, Negara Hukum, Demokrasi dan Judicial Review, Yogyakarta, UII Press.

Nukthoh Arfawie Kurde. 2005, Telaah Kritis Teori Negara Hukum: Konstitusi dan Demokrasi dalam Kerangka Pelaksanaan Desentralisasi dan Otonomi Daerah Berdasarkan UUD 1945, Yogyakarta, Pustaka Pelajar. 
Panduan Pemasyarakatan Undang-Undang Dasar Negara Republik Indonesia Tahun 1945 dan Ketetapan Majelis Permusyawaratan Rakyat Republik Indonesia. 2012, Edisi Revisi, Cetakan Kesebelas, Jakarta, Sekretariat Jenderal MPR RI.

Risalah Perubahan Undang-Undang Dasar Negara Republik Indonesia Tahun 1945, Tahun Sidang 2001, Buku II, Edisi Revisi, Jakarta, Sekretariat Jenderal MPR RI.

Romi Librayanto. 2008, Trias Politika dalam Struktur Ketatanegaraan Indonesia, Makassar, PuKAP Indonesia.

JURNAL

Prayudi, 2007, RJPN Tahun 2005-2025 Sebagai Landasan Pembanguan Politik Memperkuat Demokrasi, Jurnal Konstitusi, Volume 4, Nomor 3.

Sumardi, 2010, Keterkaitan Kebijakan Perkncanaan Pembangunan dan Penganggaran Daerah, Journal of Rural and Development, Volume 1 No. 1.

\section{MAKALAH}

Cholid Mahmud, Reformulasi GBHN: Menguatkan Kedudukan Pedoman pembangunan Nasional, Disampaikan dalam FGD tentang "Reformulasi Model GBHN: Upaya Mewujudkan Kesatuan Sistem Perencanaan Pembangunan Nasional dan Daerah", yang diselenggarakan UGM bekerjasama dengan MPR RI, Yogyakarta, Kamis, 6 September 2012.

Deddy Supriady Bratakusumah, Implikasi Perubahan UUD 1945 Terhadap Sistem Perencanaan Pembangunan Nasional, Disampaikan pada Seminar Nasional Sistem Perencanaan Pembangunan Nasional dan Ekonomi Politik Baru Pasca Amandemen UUD 1945, diselenggarakan oleh Forum Regional Program Studi IImu Perencanaan Pembangunan Wilayah dan Perdesaan, Program Pascasarjana IPB bekerjasama dengan Himpunan Perencana Wilayah dan Perdesaaan, Jakarta, 2 Juli 2003

M.Solly Lubis, Reformasi Politik Hukum: Syarat Mutlak Penegakan Hukum yang Paradigmatik, Disampaikan pada ulang tahun ke 80. M. Solly Lubis pada tanggal 11 Februari 2010.

Copyright $@$ 2016, LITIGASI, p-ISSN: 0853-7100; e-ISSN: 2442-2274 
Robinson Sembiring, Governance dengan atau Tanpa GBHN, Disampaikan dalam rangka FGD dengan Tema Menggagas Kembali GBHN sebagai Arah Perencanaan Pembangunan Nasional, yang diselenggarakan atas kerjasama antara MPR dengan USU, Medan, tanggal 19 Juli 2005.

\section{PERATURAN PERUNDANGAN}

UUD Negara Republik Indonesia Tahun 1945 sebelum dan sesudah amandemen.

Ketetapan MPR Nomor IV/MPR/1999 Tentang Garis-Garis Besar Haluan Negara Tahun 1999-2004.

Undang-Undang Nomor 25 Tahun 2004 Tentang Sistem Perencanaan Pembangunan Nasional (SPPN)

Undang-Undang Nomor 17 Tahun 2007 Tentang Rencana Pembangunan Jangka Panjang Nasional Tahun 2005-2025. 